\title{
Archaeology of disaster in Indonesia: where are we now?
}

\author{
Truman Simanjuntak ${ }^{1}$ and Marlon Ririmasse ${ }^{2}$ \\ ${ }^{1}$ Center of Prehistory and Austronesian Studies \\ ${ }^{2}$ National Research Centre for Archaeology
}

\begin{abstract}
Natural disasters are a phenomenon that shaped the Indonesian Archipelago. Earthquakes and volcanic activities have become periodic experiences in the lives of people in this region. The geographical characteristics of Indonesia which are located at the confluence of active plates and part of the global volcanic chain are natural factors that make these islands vulnerable to disasters. Cultural historical studies have recorded various phenomena of past natural disasters in the archipelago. Some have had minimal impact, but others have resulted in the loss of civilization. Although the issue has become the important part of the civilization and profile of Indonesia, the archaeological study of disasters has not well developed. The existing studies so far are still very partial with the fragmentary results. Characterized with this complex character, the study of archaeological disaster requires a multidisciplinary approach. This paper attempts to discuss the archaeology of disasters in Indonesia including the background, current conditions and the prospects of future development. Particularly in discussing the role of local wisdoms in dealing with disasters as part of the civilization of the archipelago.
\end{abstract}

Keywords: archaeology, natural disasters, cultural history, civilization

\footnotetext{
Copyright (C2021. FOSI. All rights reserved.

A Special Publication of abstracts and extended abstracts from the conference in honor of the retirement of Prof. Yahdi Zaim, IPU (22-23 March 2021).
} 


\section{INTRODUCTION}

Indonesia is a region with a geographical profile that is closely related to the natural disaster issues. Located at the junction of three tectonic plates: the Indo-Australian Plate, the Eurasian Plate and the Pacific Plate; makes more than twothirds of Indonesia's territory prone to earthquakes or vulnerable to the effects of the events. Apart from being traversed by the three tectonic plates, Indonesia is also part of the Pacific active volcanic route known as the Pacific Ring of Fire. As the impact, this region has 240 volcanoes with 70 of them in active status.

With such conditions, it is natural that the disasters characterized the history of the Indonesian archipelago. Some of them are even recorded as megadisasters with the global impact. The Toba; the Tambora; the Krakatau eruptions are some of the events. Ancient records have also mentioned numbers of disasters that have change the course of history in the region. The eruption of Mount Merapi which made the Old Mataram Kingdom move to East Java is a famous one.

Despite these major references of the past, the study of archaeological disasters has not yet developed well in Indonesia. Some preliminary studies have been conducted with fragmentary results. A multidisciplinary approach needs to strengthen those results. This paper tries to discuss the recent condition of disaster archaeological studies in Indonesia; review the previous research records and discuss the future prospect to elaborate the local wisdom perspective in developing disaster mitigation approaches.

\section{RESULTS}

A disaster is defined as a serious disruption to a functioning society, causing widespread harm to human life in material, economic or environmental terms and which exceeds the ability of the communities concerned to cope with using their own resources (UNISDR 2009).

The United Nations agency in charge of handling disasters, the UNISDR, stated that there are three main types of disasters, namely natural disasters, non-natural disasters and social disasters. Natural disasters are disasters caused by natural factors such as volcanic eruptions, earthquake, tsunamis, floods and others. Non-natural disasters by nonnatural events or series of events, which include technological failures, modernization failures, epidemics, and disease outbreaks. A social disaster is a disaster caused by an event or series of events caused by humans, which includes social conflicts between groups or between communities, and terror.

This paper will focus on the first category, namely natural disaster which can be divided into three types of events: 1. Hydro-meteorological disasters in the form of floods, typhoons, and landslides 2. Geophysical disasters in the form of earthquakes, tsunamis and volcanic 
activities 3. Biological disasters in the form of epidemics and related events.

Cultural historical records have shown that that the efforts to share these issues have begun thousands of years ago. The story of the buried city of Pompei due to the eruption of Mount Vesuvius in $79 \mathrm{AD}$ is perhaps one of the most recognizable catastrophic moments in history (Zuccaro et al., 2008). Pompei is now one of the most famous archaeological sites with the theme of disasters and has been designated as a world heritage by UNESCO. Even today, the archaeological research activities are still being carried out to explain human cultural practices in dealing with catastrophic phenomena.

Indonesia as a geographical unit also records major disasters that have regional and even global impacts. One of the earliest was the eruption of the ancient Toba Volcano which occurred approximately 74 Kya and was recorded as a mega-disaster due to the impacts for the climate, ecosystem and human population in the Prehistoric era. As an ancient volcanic activity, this eruption is thought to have triggered the massive volcanic winter during the Quaternary period.

In the framework of the historical archaeology, the most famous records are probably represented by the eruption of Mount Merapi in the 10th century which made the King Sindok, decided to move the center of the Ancient Mataram Kingdom in Central Java to Kadiri in East side of the island.
Another major disaster in the archipelago that had massive implications was the eruption of Mount Tambora on the island of Sumbawa. This mountain erupted in April 1815 and was recorded as one of the most powerful eruptions with a scale of 7 on the volcanic explosion index. Sources from colonial times mentioned that this eruption claimed the lives of more than 90,000, more than half of the population of Sumbawa at that time. This incident was also well recorded in the local historical source of the Syair Kingdom of Bima written by Lukman Hakim that describes the horror of the Tambora eruption. The eruption even resulted in global climate change a year later, when northern region of the Earth including Europe and North America experienced a phenomenon called a 'year without a summer' (Sutawijaya et al., 2006).

Characterized by these major natural events, civilizations of the region have adapted to this condition by developing response model based of this knowledge. The Hoabinhian coastal village, the diversion of the river Gomato by the king of Tarumanagara, and the ancient settlements in eastern Indonesia are several examples to be mentioned.

\section{CONCLUSION}

Cultural history has recorded that the Indonesia archipelago has been characterized by major events of natural disasters in the past. The geographical profile of the region as the meeting zone for global tectonic plates 
and part of the Pacific Ring of Fire are the main factors for the issue.

Archaeological studies share the knowledge that disasters in Indonesia have existed since the prehistoric period. Some of the events are megadisasters that brought transformation to the civilization of this region. Cultural response as a form of adaptation is also identified by cultural evidence such as architecture, landscape modification as well traditional settlement approaches.

Several research regarding this issue have been conducted but still very preliminary and fragmented. Therefore, the archaeological study of disasters in Indonesia is still potential to be explored. One of the most effective approaches is by adopting the multidisciplinary study to provide a better perspective of past disasters and formulate a form of knowledge based on local wisdom for the development of disaster mitigation in Indonesia.

\section{ACKNOWLEDGEMENTS}

Appreciation and gratitude go to the committee who has given us the opportunity to participate in this honorable forum and of course with the highest respect to Prof. Zaim for his contributions, dedication and inspiration in science and development of Indonesian archaeology.

\section{REFERENCES}

Arif, A., 2006. Jurnalisme Bencana, Bencana Jurnalisme. Jakarta: KPG.
Boelens, G., van Frassen, C. and Straver, H., 2001. Natuur en samenleving van de Molukken. Utrecht: Landelijk Steunpunt Educatie Molukkers.

Lape, P.V., 2000 Contact and Conflict in the Banda Islands, Eastern Indonesia. 11th17th Centuries. PhD Dissertation. Brown University.

Leirissa, R.Z.; Pattykaihattu, J.A.; Luhukay, H.; Talib, U. and Maelissa, S., 2004. Ambonku: doeloe, kini dan esok. Ambon: Pemerintah Kota Ambon.

Meier, H-R., 2007. The Cultural Heritage of the Natural Disaster: Learning Processs and Projections from the Deluge to the $>>$ Live $<<$ Disaster on TV. Dresden: Technishce Universitat Dresden. Meier, H.-R., Petzet, M. and Will, T., 2007. Cultural Disaster and Natural Disasters: Risk Preparedness and the Limits of Prevention. Dresden: Technische Universitat Dresden. Hal. 23-40.

Noerwidi, S., 2012. Younger Toba tephra 74 Kya: Impact on regional climate, terrestrial ecosystem and prehistoric human population, Amerta Volume 30 Nomor 1. Jakarta: Pusat Arkeologi Nasional.

Noto, T., 1993. Koukoiseki ni miru Joushu no Kazansaigai, Kazanbai koukogaku. Pp. 54-82. Tokyo: Kokin Shoin. Shimoyama, Satoru. 2002. Basic characteristics of disasters. Torrence, Robin dan Gratttan, John (Editor). 2002. Natural Disaster and Cultural Change. London: Routledge. Hal. 19-27. 
Shimoyama, S., 1998. Issues on the disaster assessment. Retto no koukogaku, 713- 32. Tokyo: Watanae Maktoto Sensei Kanrekikinen Ronshu Kankoukai, Soloviev, S.L; Go, CH N; KH. S. Kim. 1992. Catalogue of the Tsunami in the Pacific 1969- 1982. New Delhi: Amerind Publishing Co. Pvt. Ltd.

Sutawijaya, I.S., Sigurdsson, H. and Abrams, L., 2006. Characterization of volcanic deposits and geoarchaeological studies from the 1815 eruption of Tambora volcano. Jurnal Geologi Indonesia Volume 1 Nomor 1 Maret 2006. Hal. 49-57.
Torrence, R. and Grattan, J., 2002. The archaeology of disasters: past and future trends.

Torrence, R. dan Gratttan, J. (eds.), 2002. Natural Disaster and Cultural Change. London: Routledge. hal.1-18.

Utomo, B.B., 2006. Kalau Gunung itu Meletus. Kompas 22 Mei 2006.

Zuccaro, G., Cacace, F., Spence, R. and Baxter P., 2008. Impact of explosive eruption scenario at Vesuvius. Journal of Vulcanology and Geothermal Research Vol. 178. Issue 3. Pp. 416-453. 